\title{
Pendekatan Conjoint Analysis untuk Mengukur Tingkat Preferensi Mahasiswa terhadap Layanan Sistem Informasi Akademik di UIN Yogyakarta
}

\author{
Epha Diana Supandi \\ Program Studi Matematika Fakultas Sains dan Teknologi, UIN Sunan Kalijaga, JI. Marsda Adisucipto \\ No. 1 Yogyakarta, Indonesia
}

Korespondensi; Email: ephadiana@yahoo.com

\begin{abstract}
Abstrak
Teknologi Informasi ( $\mathrm{TI}$ ) merupakan salah satu indikator utama untuk mendukung suasana akademik di universitas. Oleh karena itu UIN Sunan Kalijaga (Suka) Yogyakarta telah memiliki teknologi informasi Sistem dan itu disebut Sistem Informasi Akademik (SIA). UIN Suka harus memiliki preferensi pengetahuan dan persepsi konsumen terhadap layanan, yang seperti apa yang dibutuhkan oleh konsumen. Dengan menggunakan metode Analisis Conjoint akan kombinasi yang diperoleh dari faktor tingkat-tingkat (stimuly) yang disukai oleh konsumen sesuai dengan nilai utilitas tertinggi dari setiap faktor tingkat. Tujuan dari penelitian ini adalah untuk mengukur tingkat preferensi konsumen (siswa) dengan SIA jasa di UIN Suka menggunakan metode Analisis Conjoint. Hasil penelitian menunjukkan bahwa faktor yang paling penting dalam menggunakan layanan SIA adalah manfaat (nilai pentingnya adalah $66.623 \%$, faktor penting kedua adalah accesibility dari SIA (nilai pentingnya adalah $19.227 \%$ ) dan yang penting terakhir adalah kemampuan staf (nilai pentingnya adalah $14,15 \%$ ). Menurut nilai estimasi utilitas, hal itu menunjukkan bahwa konsumen ingin menggunakan SIA untuk kunci dalam program (estimasi utilitas 2.104), layanan online (estimasi utilitas 0577) dan staf SIA yang sangat ramah ketika mereka melayani siswa (estimasi utilitas 0210).
\end{abstract}

Kata Kunci: Analisis conjoint; Preferensi; Kegunaan

\begin{abstract}
Information Technology (IT) represent one of main indicator to support the academic atmosphere at the university. Therefore UIN Sunan Kalijaga (Suka) Yogyakarta has owned sistem information technology and it is called Academic Information System (SIA). UIN Suka shall has knowledge preference and perception of consumer to the service, which is like what required by consumer. By using Conjoint Analysis method would have been obtained combination from level-level factor (stimuly) took a fancy by consumer according to value of highest utility from every level factor. The objective of this research is to measure preference level of consumers (students) to the SIA services in UIN Suka used Conjoint Analysis method. The result shows that the most important factor in using SIA service is the benefit (importance value is $66,623 \%$, the second important factor is accesibility of SIA ( importance value is $19,227 \%$ ) and the last important is ability of staff (importance value is $14,15 \%$ ). According to value of utility estimate, it shows that consumers like to use SIA for key in courses (utility estimate is 2,104), online service (utility estimate is 0,577 ) and SIA staff who are very friendly when they were servicing the students (utility estimate is $\mathbf{0 , 2 1 0 )}$.
\end{abstract}

Keywords: Conjoint analysis; preference; utility

\section{Pendahuluan}

Universitas Islam Negeri (UIN) Sunan Kalijaga (Suka) Yogyakarta sebagai salah satu lembaga pendidikan tinggi, telah mendapatkan ISO 9001-2008 sebagai bukti bahwa UIN Yogyakarta telah menerapkan Quality Assurance (QA). Hal ini mengakibatkan bahwa UIN Yogyakarta harus menerapkan standar mutu didalam sistem manajemennya. Dalam usaha standarisasi mutu setiap jasa Perguruan Tinggi, 
standar- standar proses dan system yang diperlukan haruslah diupayakan secara maksimal. UIN Yogyakarta harus menerapkan konsep mengutamakan kepuasan mahasiswa, karena di dalam manajemen mutu terpadu perguruan tinggi, mahasiswa merupakan pelanggan yang harus dipenuhi kebutuhannya secara optimal.

Beberapa bidang pelayanan yang harus dikembangkan secara berkelanjutan meliputi: kurikulum program studi, proses pembelajaran, sumber daya manusia (dosen, pegawai, teknisi), sarana dan prasarana, suasana akademik, penelitian serta publikasi, pengabdian kepada masyarakat, manajemen lembaga, sistem informasi, dan bidang-bidang lain yang berhubungan dengan kegiatan akademik.

Salah satu bentuk komitmen UIN Yogyakarta terhadap kualitas pelayanan terhadap mahasiswa, UIN Yogyakarta telah membangun fasilitas pendukung yaitu pelayanan Sistem Informasi Akademik (SIA) online. Kegiatan yang dilaksanakan oleh SIA online untuk memenuhi kebutuhan akademik mahasiswa, seperti Kartu Rencana Studi (KRS) maupun Kartu Hasil Studi (KHS). Selain itu manfaat SIA Online juga adalah mahasiswa dapat Key In mata kuliah dan melihat jadwal kuliah.

Sarana dan prasarana yang dibangun diharapkan dapat mendukung berlangsungnya atmosfir kegiatan akademis di UIN Sunan Kalijaga Yogyakarta. Pada aktivitas pelayanan yang diberikan tersebut, masih terdapat kemungkinan mahasiswa kurang merasa terpuaskan karena adanya atribut pelayanan yang dianggap tidak optimal.

Mahasiswa UIN Yogyakarta sebagai customer dari perguruan tinggi tentunya mempunyai harapan yang beragam terhadap pelayanan SIA. Untuk mengetahui harapan apa saja yang saat ini diinginkan oleh mahasiswa, sejauh mana pelayanan itu diberikan dan bagaimana tingkat kepuasan pelayan SIA di UIN Yogyakarta serta bagaimana perilaku pengguna layanan SIA di UIN Yogyakarta, maka perlu dibuat suatu penelitian dengan menggunakan analisa statistik guna mendapatkan data yang akurat mengenai pelayanan yang telah diberikan oleh UIN Yogyakarta. Hasil penelitian ini diharapkan dapat mengetahui hal-hal apasaja yang perlu diprioritaskan untuk segera ditangani, sehingga perbaikan kualitas pelayanan SIA UIN Yogyakarta lebih efektif dan terarah.

Di dalam pengolahan data, ada banyak metode statistika yang dapat digunakan, dan salah satunya adalah Analisis Konjoin (Conjoint Analysis). Analisis konjoin dipilih karena, analisis ini dapat menguji stimulus yang dievaluasi responden secara mendetail dimana stimulus tersebut merupakan kombinasi dari semua tingkat atau level setiap atribut dari objek yang sedang diteliti tersebut [6].

Analisis konjoin adalah salah satu analisis statistika multivariat yang dapat digunakan untuk mendapatkan kombinasi atau komposisi atribut-atribut suatu produk atau jasa baik yang baru maupun yang lama yang paling disukai konsumen sehingga dapat diketahui preferensi konsumen terhadap suatu produk atau jasa tersebut [5].

Berdasarkan hal-hal tersebut, maka menarik untuk dilakukan suatu penelitian mengenai tingkat preferensi mahasiswa terhadap layanan SIA di UIN Sunan Kalijaga dengan menggunakan Conjoint Analysis.

\section{Landasan Teori}

\section{Teori Perilaku Konsumen}

Teori perilaku konsumen yaitu teori yang menjelaskan tindakan konsumen dalam mengkonsumsi barangbarang, dengan pendapatan tertentu dan harga barang tertentu pula sedemikian rupa agar konsumen mencapai tujuannya. Tujuan konsumen untuk memperoleh manfaat atau kepuasan sebesar- besarnya dari barang-barang yang dikonsumsi (maximum satisfaction). Teori ekonomi menganggap bahwa maximum satisfaction adalah tujuan akhir konsumen.

Beberapa anggapan-anggapan sederhana yang biasa menjadi patokan untuk menganalisa pembentukan garis permintaan dari suatu barang secara lebih tepat, tanpa menyimpang dari realitas ekonomi [7].

Barang dan jasa yang dikonsumsi biasanya disebut komoditi. Komoditi adalah sesuatu yang memberikan jasa konsumsi (consumption services) terhadap konsumen persatuan waktu tertentu.

1. Setiap konsumen dianggap tahu macam barang dan jasa yang tersedia di pasar, kapasitas teknis masing-masing barang dan jasa dalam memenuhi kebutuhan konsumen dan tingkat harga masing-masing. 
2. Konsumen dianggap tahu secara pasti mengenai jumlah uang yang akan dibelanjakanya selama periode perencanaan tertentu.

\section{Teori Nilai Guna (Utility)}

Secara historis, teori nilai guna (utility) merupakan teori yang terlebih dahulu dikembangkan untuk menerangkan kelakuan individu dalam memilih barang-barang yang akan dibeli dan dikonsumsinya. Dapat dilihat bahwa analisis tersebuttelah memberi gambaran yang cukup jelas tentang prinsip-prinsip pemaksimuman kepuasan yang dilakukan oleh orang-orang yang berfikir secara rasional dalam memilih berbagai barang keperluannya.

Teori nilai guna atau utility yaitu teori ekonomi yang mempelajari kepuasan atau kenikmatan yang diperoleh seorang konsumen dari mengkonsumsikan barang-barang. Kalau kepuasan itu semakin tinggi maka semakin tinggi nilai guna atau utility-nya. Sebaliknya semakin rendah kepuasan dari suatu barang maka utilitynya semakin rendah pula [7].

Nilai guna dibedakan diantara dua pengertian:

1. Marginal utility (kepuasan marginal). Yaitu pertambahan/pengurangan kepuasan sebagai akibat adanya pertambahan/pengurangan penggunaan satu unit barang tertentu.

2. Total utility (utilitas total). Yaitu keseluruhan kepuasan yang diperoleh dari mengkonsumsi sejumlah barang-barang tertentu.

Sementara M Abraham Garcia-Torres (2011) dalam membagi nilai guna menjadi dua. Berdasarkan dua tindakan ekonomi yang dilakukan konsumen, dua tindakan ini saling berhubungan [8]:

1. "Nilai Guna Keputusan (Decision Utility)" yang berhubungan dengan Tindakan pembelian (action of Purchasing)". Dalam tindakan pembelian konsumen membeli beberapa barang pada waktu yang bersamaan. dan sebelum melakukan pembelian konsumen harus memutuskan barang yang mana yang akan dia beli.

2. "Nilai Guna Pengalaman (Experienced Utility)" Yang berhubungan Dengan Tindakan Konsumsi (action of Consumption) dengan kapasitas pemenuhan kepuasan dari barang tersebut.

\section{Teori Preferensi Konsumen}

Ketika mengkonsumsi sejumlah komoditi dalam periode tertentu, Setiap konsumen akan mendapatkan kepuasan (satisfaction) atau guna (utility). Setiap konsumen selalu berusaha untuk mendapatkan tingkat kepuasan semaksimal mungkin dari sejumlah pengeluaran yang sudah mereka lakukan. untuk keperluan tersebut setiap konsumen harus bisa membuat urutan (rank) dari semua untaian komoditi yang ada. Mereka harus bisa menentukan untaian komoditi mana yang lebih mereka pilih, mana yang tidak dan mana yang relatif jika dibandingkan dengan yang lain.

\section{Analisis Konjoin}

Analisis konjoint adalah salah satu teknik analisis yang termasuk ke dalam analisis multivariat. Analisis konjoin ini mencoba menentukan kepentingan relatif yang dikaitkan pelanggan pada atribut yang penting dan utiliti yang mereka kaitkan pada tingkatan atau level atribut.

Asumsi yang mendasari teknik ini adalah bahwa setiap stimulus, seperti produk, merek atau toko dievaluasi sebagai perangkat atribut atau bundle of atributies. Analisis konjoin membangun atau mengembangkan parth-worth atau fungsi utility (fungsi kegunaan/manfaat).

Model dasar conjoint analysis dapat dirumuskan sebagai berikut [2]:

$$
U(x)=\sum_{i=1}^{m} \sum_{j=1}^{k_{i}} a_{i} x_{i}
$$

dengan,

$U(x)=$ seluruh utility dari suatu alternatif (overall utility of an alternative)

$a_{i} \quad=$ sumbangan utility yang terkait dengan level ke-j

$k_{i} \quad=$ banyaknya level atribut $\mathrm{i}$

$m \quad$ = banyaknya atribut

$i \quad=1,2, \ldots, \mathrm{m}$ (atribut ke-i) 
$j \quad=1,2, \ldots, \mathrm{ki}_{\mathrm{i}}$ (level ke-j)

$x_{i}=1$; apabila level ke-j dari atribut ke-I terjadi

$=0$; apabila tidak

Pentingnya suatu atribut, misalnya $l_{i}$ didefinisikan dan dinyatakan dalam kisaran parth-worth yang melintasi level dari atribut, yaitu:

$$
I_{i}=\left\{m \quad\left(a_{i}\right)-m\left(a_{i}\right)\right\}, \text { untuk setiap } i
$$

Pentingnya atribut, dinormalkan (normalized) untuk meyakinkan kepentingan relatifnya dengan atribut lainnya, $W_{i}$

$$
W_{i}=\frac{I_{i}}{\sum_{i=1}^{m} I_{i}}
$$

Sehingga $\sum_{i=1}^{m} W_{i}=1$

Ada beberapa istilah yang digunakan dalam melakukan analisis konjoin [4], yaitu:

- Parth-worth functions/ utility function ialah kegunaan (utility) yang dikaitkan oleh pelanggan pada sub atribut tingkatan/level/ setiap atribut

- Relative importance weight ialah nilai yang bisa menunjukkan atribut mana yang penting tingkatan/level/di dalam mempengaruhi pilihan pelanggan.

- Internal validity meliputi korelasi antara evaluasi hold out yang diprediksi atau validitasi stimulus dengan hasil yang diperoleh dari para pelanggan.

- Full profiles atau complete profiles adalah merek yang dibentuk dinyatakan dalam semua atribut dengan menggunakan atribut level yang ditentukan oleh desain.

- Cylical designs ialah desain yang dipergunakan untuk mengurangi banyaknya pasangan yang harus diperbandingkan.

- Factional factorial design ialah desain yang dipergunakan untuk mengurangi banyaknya profile stimulus yang dievaluasi di dalam pendekatan profil penuh.

- Orthogonal arrays ialah sebuah kelas desain faktorial yang memungkinakan untuk membuat perkiraan yang efisien dari seluruh pengaruh utama (Main effects).

[6]:

Adapun langkah-langkah kegiatan yang harus dilakukan di dalam analisis konjoin sebagai berikut

a. Merumuskan masalah (problem formulation) mencakup kegiatan mengenali atau mengidentifikasi atribut-atribut yang penting dan tingkatan/levelnya.

b. Membentuk Stimulus

Ada dua cara pembentukan stimulus dalam analisis konjoin yaitu pendekatan pasangan (pairwise approach) dan prosedur profil penuh (full profile procedure). Di dalam pendekatan pasangan, responden menilai dua atribut setiap kali sampai semua kemungkinan pasangan dua atribut telah selesai dievaluasi. Di dalam pendekatan profil penuh, semua merek dibentuk dari semua atribut, sehinngga terbentuk profil penuh atau lengkap. Atribut dan tingkatan level dipergunakan untuk membentuk stimulus yang akan dipergunakan dalam analisis konjoin

c. Menentukkan Bentuk Data Input.

Di dalam analisis konjoin bentuk input data bisa kualitatif (non metrik) ataupun data kuantitatif (metrik). Untuk data non metrik responden diminta untuk memberikan evaluasi peringkat (rank). Di dalam data metrik responden memberikan rating.

d. Prosedur Analisis Konjoin

Setelah responden menilai (to rate) atau membuat peringkat (to rank) stimulus dengan menggunakan skala yang tepat dan data yang diperoleh kemudian di analisis.

e. Penilaian Keandalan dan Kesahihan 
Ketepatan/ kecocokan dari estimasi model harus dievaluasi. Beberapa prosedure tersedia untuk menilai keandalan (reliabilty) dan kesahihan (validity).

- Uji keandalan yang diulang (test-retest reliability) bisa dievaluasi dengan mendapatkan beberapa pertimbangan yang diulang ( $f e w$ replicated judgements). Dengan perkataan lain, pada tahap kemudian, dalam wawancara, responden diminta untuk mengevaluasi lagi stimulus tertentu yang dipilih. Dua nilai dari stimulus dari stimulus ini kemudian dikorelasikan untuk menilai test-retes reliability.

- Evaluasi untuk stimuly hold out or validation dapat diprediksi dengan fungsi part-worth yang diestimasi.

- Evaluasi yang diprediksi kemudian dikorelesaikan dengan yang diperoleh dari responden untuk menentukan internal validity.

- Kalau analisi tingkat/level agregrat telah dilakukan, estimasi sampel dapat dipecah dengan beberapa cara, dan analisi konjoin dilakukan untuk sub sample untuk mengevaluasi stabilitas dari pemecahan analisis konjoin.

\section{Metodologi Penelitian}

\section{Waktu dan Lokasi Penelitian}

Penelitian ini dilakukan sejak Juli 2011 sampai Oktober 2011. Lokasi penelitian di kampus UIN Sunan Kalijaga (Suka) Yogyakarta.

\section{Desain dan Teknik Pengambilan Sampel}

Penelitian ini dilakukan melalui survei dengan metoda wawancara langsung dan tatap muka dengan responden. Responden diambil secara proposional random sampling. Dengan metoda ini periset menentukan sampel berdasarkan pertimbangan jumlah mahasiswa aktif di tiap fakultas.

Fakultas yang memiliki jumlah mahasiswa aktif akan diwakili oleh sampel yang lebih banyak dibandingkan fakultas yang mahasiswa aktifnya lebih sedikit. Harapannya sampel yang diambil lebih bisa mewakili keadaan populasi.

\section{Analisis Data}

\begin{tabular}{|c|c|c|}
\hline \multirow{4}{*}{ Tahap 1} & \multicolumn{2}{|r|}{ Menentukkan atribut/faktor dan sub atribut/level } \\
\hline & Metode & Observasi dan wawancara \\
\hline & Peserta & Mahasiswa selaku konsumen dan pihak pemberi layanan (pengurus) \\
\hline & Tujuan & $\begin{array}{l}\text { Mengetahui faktor-faktor yang dibutuhkan dan diinginkan dalam proses keputusan } \\
\text { menggunakan jasa pelayanan fasilitas di UIN Yogyakarta }\end{array}$ \\
\hline \multirow{5}{*}{ Tahap 2} & & $\sqrt{2}$ \\
\hline & \multicolumn{2}{|r|}{ Menentukkan skenario kuesioner } \\
\hline & Metode & Reduksi dengan program SPSS \\
\hline & Peserta & Peneliti \\
\hline & Tujuan & Menentukkan bentuk kuesioner \\
\hline \multirow{4}{*}{ Tahap 3} & & $\nabla$ \\
\hline & \multicolumn{2}{|r|}{ Menentukan Preferensi Konsumen/Mahasiswa } \\
\hline & Metode & Survei dengan kuesioner dengan skala rating \\
\hline & Tujuan & Mengetahui atribut yang disukai dan tidak disukai \\
\hline \multirow{4}{*}{ Tahap 4} & 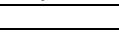 & 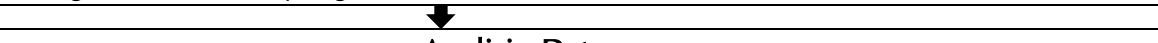 \\
\hline & \multicolumn{2}{|r|}{ Analisis Data } \\
\hline & Metode & Analisis Konjoin dengan program SPSS [1] \\
\hline & Tujuan & $\begin{array}{l}\text { Mendapatkan rata-rata kepentingan (averaged importance) faktor dan kepuasan } \\
\text { (utility) setiap sub atribut. }\end{array}$ \\
\hline \multirow[b]{2}{*}{ Tahap 5} & \multicolumn{2}{|r|}{ Hasil dan Rekomendasi } \\
\hline & Tujuan & $\begin{array}{l}\text { 1. Mengetahui preferensi mahasiswa terhadap pelayanan fasilitas } \\
\text { 2. Mengukur tingkat kepuasan mahasiswa } \\
\text { 3. Usulan perbaikan layanan } \\
\text { 4. Peningkatan kualitas layanan }\end{array}$ \\
\hline
\end{tabular}

Gambar 1 Alur Tahapan Penelitian. 
Analisis data yang digunakan dalam penelitian ini adalah dengan analisa konjoin dengan menggunkan software SPSS (Statistical Package for Social Sciences). Adapun tahap-tahap penelitiannya adalah seperti pada gambar 1.

\section{Hasil dan Pembahasan}

\section{Hasil Penelitian}

Hasil rekapitulasi mahasiswa yang mendaftar/heregistrasi pada semester genap TA 2010/2011 menurut data dari Bagian Akademik UIN Suka ada sebanyak 12.356 orang. Penentuan responden pada penelitian ini dengan menggunakan teknik proposional random sampling. Dimana tujuannya adalah setiap fakultas dapat diwakili oleh mahasiswa sesuai dengan jumlah mahasiswa di masing-masing fakultas. Adapun responden yang akan diambil di tiap fakultas dapat dilihat pada tabel di bawah ini.

Tabel 1 Jumlah mahasiswa aktif dan sampel responden di tiap Fakultas.

\begin{tabular}{clrr}
\hline No & \multicolumn{1}{c}{ Fakultas } & Jumlah & Sampel \\
\hline 1 & Adab dan Ilmu Budaya & 1686 & 20 \\
2 & Dakwah & 1266 & 15 \\
3 & Syari'ah dan Hukum & 2354 & 29 \\
4 & Tarbiyah dan Keguruan & 2551 & 31 \\
5 & Ushuludin, Pemikiran Islam dan Studi Agama & 982 & 12 \\
6 & Sains dan Teknologi & 2483 & 30 \\
7 & Ilmu Sosial dan Humaniora & 1034 & 13 \\
\hline & & 12356 & 150 \\
\hline
\end{tabular}

Untuk mengukur tingkat preferensi mahasiswa terhadap layanan Sitem Informasi Akademik (SIA) dengan menggunakan analisis konjoin. Pada kasus ini menggunakan 3 atribut yaitu manfaat, akses, petugas SIA. Masing-masing atribut tersebut diturunkan lagi menjadi sub atribut. Atribut manfaat terdiri dari tiga level/sub atribut yaitu key in mata kuliah, melihat KHS (Kartu Hasil Studi) dan melihat jadwal kuliah. Sub atribut akses SIA terbagi menjadi 2 level saja yaitu online dan melalui GODAM. Atribut petugas terdiri dari 2 sub atribut yaitu keramahan dan kecepatan.

Hasil pengolahan dengan menggunakan SPSS 16 dapat dilihat pada tabel di bawah ini:

Tabel 2 Tingkat Utility.

\begin{tabular}{lccc}
\hline & & $\begin{array}{c}\text { Utility } \\
\text { Estimate }\end{array}$ & Std. Error \\
\hline Manfaat & 1,00 & 2,104 & 0,127 \\
& 2,00 & 0,073 & 0,127 \\
& 3,00 & $-2,177$ & 0,127 \\
Akses & 1,00 & 0,575 & 0,090 \\
& 2,00 & $-0,575$ & 0,090 \\
Petugas & 1,00 & 0,210 & 0,090 \\
& 2,00 & $-0,210$ & 0,090 \\
\hline (Constant) & & 6,500 & 0,090 \\
\hline
\end{tabular}

Nilai utility yang positif menunjukkan bahwa responden menyukai sub atribut yang ditawarkan, sedangkan nilai utilty negatif menyatakan sebaliknya (tidak menyukai sub atribut yang ditawarkan). Pada atribut manfaat SIA responden lebih menyukai level/sub atribut key in mata kuliah. Hal ini ditunjukkan dengan utility tertinggi sebesar 2,104. Selain manfaat untuk key in mata kuliah ternyata mahasiswa juga merasa puas (menyukai) kegunaan SIA untuk melihat KHS $(0,073)$ dibandingkan dengan manfaat SIA sebagai cara untuk melihat jadwal kuliah $(-2,177)$. Sedangkan atribut akses 
responden menyukai mengakses SIA dengan cara online dengan nilai utility sebesar 0,575 dan tidak menyukai mengakses SIA melalui GODAM di kampus ditunjukkan dengan nilai utility negatif yaitu sebesar -0,575. Faktor karyawan ternyata responden lebih menyukai karyawan yang ramah dalam melayani keluhan mahasiswa $(0,210)$ dibandingkan kecepatan layanan petugas SIA $(-0,210)$.

Analisis konjoin mengenai tingkat kepentingan relatif mahasiswa terhadap layanan SIA dapat dilihat pada tabel di bawah ini:

Tabel 3 Tingkat Kepentingan Relatif.

\begin{tabular}{lc}
\hline Atribut & Nilai Kepentingan relatif $\left(\mathrm{W}_{\mathbf{i}}\right)$ \\
\hline Manfaat & 66,623 \\
Akses & 19,227 \\
Petugas & 14,150 \\
\hline
\end{tabular}

Berdasarkan tabel di atas dapat dijelaskan bahwa responden (mahasiswa) menganggap bahwa manfaat SIA merupakan faktor atau atribut terpenting $(66,623)$. Faktor penting ke dua adalah akses menggunakan SIA (19,227\%), faktor penting ke tiga adalah petugas SIA $(14,150 \%)$.

Hasil penelitian ini dianggap valid karena valid karena angka predictive accuracy pada peringkat Pearson $(0,992)$ dan Kendal $(0,970)$ memberikan hasil korelasi yang tinggi (lebih besar dari 0.5) dengan tingkat significant yang lebih kecil dari taraf nyata $=0,05$. Hasil ini juga menggambarkan bahwa terdapat hubungan positip yang sangat kuat antara pola pendapat (estimates part-worth) dengan pendapat actual responden.

Tabel 4 Nilai Pearson dan Kendalls Tau.

\begin{tabular}{lcr}
\hline & Value & Sig. \\
\hline Pearson's R & 0,992 & 0,000 \\
Kendall's tau & 0,970 & 0,000 \\
\hline $\begin{array}{l}\text { a. Correlations between observed } \\
\text { and estimated preferences }\end{array}$ \\
\hline
\end{tabular}

Untuk mengukur tingkat kepuasan layanan SIA UIN Suka, maka variabel yang dianalisis meliputi sikap dan perilaku petugas SIA, jumlah GODAM (Gardu Online Data Anjungan Mandiri) dan total layanan secara keseluruhan.

Berdasarkan tabel terlihat bahwa sikap petugas dan perilaku petugas menurut mahasiswa sudah ramah $(40,67 \%)$ yang menjawab kurang ramah sebesar $51,33 \%$ dan yang menjawab tidak ramah ada sebanyak $8 \%$.

Tabel 5 Tingkat kepuasan mahasiswa terhadap petuga SIA.

\begin{tabular}{llrr}
\hline Atribut & Penilaian & Jumlah & Persentase \\
\hline Sikap dan Perilaku & Ramah & 61 & 40,67 \\
Petugas Kantin & Kurang Ramah & 77 & 51,33 \\
& Tidak Ramah & 12 & 8,00 \\
\hline
\end{tabular}

Hasil tabulasi juga memperlihatkan bahwa jumlah GODAM yang ada di fakultas masih kurang $(74,67 \%)$, sebanyak 32 responden menjawab jumlah GODAM di fakultas sudah cukup (21,33\%) dan yang menjawab sudah banyak ada sebanyak 6 orang saja $(4 \%)$. 
Tabel 6 Tingkat kepuasan mahasiswa terhadap jumlah GODAM.

\begin{tabular}{clrr}
\hline Layanan & Penilaian & Frekuensi & Persentase \\
\hline \multirow{3}{*}{ Jumlah GODAM } & Banyak & 6 & 4,00 \\
& Cukup & 32 & 21,33 \\
& Kurang & 112 & 74,67 \\
\hline
\end{tabular}

Menurut hasil survei, secara keseluruhan pelayanan yang diberikan oleh SIA dirasakan tidak memuaskan menurut penilaian mahasiswa. Hal ini dibuktikan dengan persentase ketidakpuasan sebesar $62 \%$. Hasil selengkapnya dapat di lihat pada tabel 4.7 .

Tabel 7 Tingkat kepuasan mahasiswa terhadap layanan SIA.

\begin{tabular}{clrr}
\hline Layanan & Penilaian & Frekuensi & Persentase \\
\hline \multirow{3}{*}{ Total layanan } & Sangat memuaskan & 2 & 1,33 \\
& Memuaskan & 55 & 36,67 \\
& Tidak Memuaskan & 93 & 62,00 \\
\hline
\end{tabular}

\section{Pembahasan Penelitian}

Karakteristik respoden berdasarkan jenis kelamin kaum perempuan $(69 \%)$ mendapat persentase lebih banyak dibandingkan laki-laki. Asal daerah responden paling banyak dari Jawa Tengah (40\%) dan DI Yogyakarta (28\%). Pekerjaan orang tua sebagian besar bekerja sebagai petani (27\%) dan PNS $(23 \%)$. Besarnya pendapatan tiap bulan orang tua sekitar $<1$ juta tiap bulan (36\%) dan sekitar 1 2 juta tiap bulan (30\%).

Sebagian besar responden tinggal di rumah orang tua (54\%), hal ini disebabkan masih banyak responden berasal dari DIY sehingga otomatis banyak yang masih tinggal di rumah orang tua. Pengeluaran responden berkisar antara 200 ribu 300 ribu ada sebanyak $36 \%$ dan antara 300 ribu 400 ribu ada sebanyak 30\%. Menurut hasil survei kebiasaan mahasiswa dalam mengakses layanan SIA setiap minggunya adalah 1-2 kali (85\%).

Tingkat kepuasan layanan SIA secara keseluruhan menurut mahasiswa tidak memuaskan (62\%). Hal ini ditunjukkan dan didukung dengan analisis kepuasan untuk layanan petugas SIA ternyata masih kurang ramah $(51,33 \%)$ dan jumlah GODAM yang ada di tiap fakultas masih dirasakan kurang memadai $(74,67 \%)$.

Dari hasil kuesioner diperoleh informasi bahwa SIA masih belum optimal hal ini dikarenakan SIA sering error dan loading lama, kemungkinan alasan-alasan tersebut yang menjadikan mahasiswa sering kecewa dan belum puas dengan layanan SIA yang ada di UIN Sunan Kalijaga.

Selain masalah sering error dan loading yang lama, mahasiswa menginginkan sistem yang ada di SIA untuk di upgrade, misalnya nilai mata kuliah yang diambil 2x (mengulang) seharusnya muncul di KHS hanya 1 nilai yang terbaik (tidak double nilai).

Pihak manajemen UIN Sunan Kalijaga dalam hal ini pengelola SIA dapat meningkatkan performance kerja. Berdasarkan hasil analisis konjoin ternyata menurut persepsi mahasiswa layanan SIA yang paling penting adalah manfaat SIA (nilai importance value sebesar 66,623\%). Dimana manfaat yang paling disukai oleh mahasiswa adalah untuk key in mata kuliah (nilai utility sebesar 2,104).

Faktor ke dua yang penting menurut persepsi mahasiswa adalah kemudahan mengakses SIA (importance values sebesar 19,227\%) dimana mahasiswa lebih menyukai mengakses SIA secara online (nilai utility sebesar 0,575).

Peningkatan layanan SIA wajib dilakukan oleh pihak pengelolanya karena Sistem Informasi Akademik sangat vital bagi kegiatan studi mahasiswa. Berdasarkan hasil dan pembahasan penelitian ini, maka ada beberapa langkah yang dapat dilakukan dalam rangka meningkatan performance SIA diantaranya adalah: 
1. Accesibility Sistem Informasi Akademik (SIA) secara online harus lebih mudah, jangan sering error dan loading jangan lama.

2. Jumlah GODAM di tiap fakultas ditambah, karena selama ini masih dirasakan kurang oleh mahasiswa.

3. Fungsi SIA sebagai layanan akademik mahasiswa seperti key in mata kuliah, melihat nilai mata kuliah, melihat KHS dan lain-lain lebih ditingkatkan lagi.

Selain masalah-masalah di atas, pelayanan SIA perlu didukung supporting data dalam hal ini nilai mata kuliah. Mahasiswa sering merasa bahwa nilai mata kuliah yang dapat di lihat di SIA sering terlambat, padahal hal tersebut berakibat kepada penentuan jumlah SKS yang akan diambil pada semester berikutnya. Oleh karena itu petugas SIA harus terus meningkatkan layanan dan lebih ramah ketika menghadapi dan melayani mahasiswa.

\section{Kesimpulan}

Berdasarkan hasil analisis tingkat kepuasan dan preferensi mahasiswa terhadap layanan SIA dapat disimpulkan sebagai berikut

1. Tingkat kepuasan mahasiswa terhadap layanan SIA masih rendah, menurut penilaian mahasiswa performance belum memuaskan. Hal ini dibuktikan dengan persentase ketidakpuasan sebesar $62 \%$.

2. Berdasarkan hasil analisis konjoin ternyata menurut persepsi mahasiswa layanan SIA yang paling penting adalah manfaat SIA (nilai importance value sebesar 66,623\%). Dimana manfaat yang paling disukai oleh mahasiswa adalah untuk key in mata kuliah (nilai utility sebesar 2,104). Faktor ke dua yang penting menurut persepsi mahasiswa adalah kemudahan mengakses SIA (importance values sebesar 19,227\%) dimana mahasiswa lebih menyukai mengakses SIA secara online (nilai utility sebesar 0,575). Sedangkan kinerja petugas menempati peringkat terakhir dengan tingkat kepentingan relatif sebesar $14,150 \%$, mahasiswa lebih menyukai petugas yang ramah dalam melayani mahasiswa (nilai utility sebesar 0,210 ).

3. Faktor-faktor penyebab ketidakpuasan mahasiswa terhadap layanan SIA adalah karena sering error dan loading lama, selain itu jumlah GODAM yang ada belum mencukupi kebutuhan mahasiswa. Penyebab lain dari ketidakpuasan mahasiswa karena fasilitas SIA belum optimal dalam menyediakan kebutuhan yang diminta mahasiswa, seperti key in mata kulian, nilai mata kuliah dan KHS

\section{Referensi}

[1] Ghozali, Imam. 2006. Aplikasi Analisis Multivariate Dengan Program SPSS. Badan Universitas Diponegoro. Semarang. [2] Gustafsson, A., et al., 2007, Conjoint Measurement methodes and Applications, fourth Editions, Springer Verlage-Berlin

[3] Hair, J. et.al. 1998, Multivariate Data Analysis, 5th edition, Prentice Hall, New-Jersey.

[4] Jhonson, R.A., and Dean, W.W., 2000. Applied Multivariate Statistical Analysis. Prentice Hall. New Jersey.

[5] Simamora, B., 2002. Analisis Multivariat Pemasaran. PT Gramedia Pustaka Utama. Jakarta.

[6] Supranto, J., 2004. Analisis Multivariat Arti dan Interpretasi. PT Rineka Cipta. Jakarta

[7] http://ramaalessandro2.multiply.com/journal/item/2. Teori Nilai Guna. Diakses 8 Mei 2011.

[8] http:// garcia.unu-merit.nl. Garcia-Torres M. Abraham, Consumer Behaviour Theory: utility Maximization and The seek Of Novelty, Diakses 8 Mei 2011. 